\title{
Analysis of Factors Influencing Agents’ Perception towards Life Insurance Corporation of India
}

\author{
Ms. Neetu Bala (Corresponding author) \\ Assistant Professor, Maharaja Agrasen College \\ University of Delhi, Delhi, India \\ Email: neetucancerion@gmail.com \\ Dr. H.S Sandhu \\ Director, SAI Technology Campus \\ Amritsar (Punjab), India \\ E-mail: sandhu_hs12@yahoo.com
}

Received: July 25, 2011 Accepted: August 11, 2011 DOI: 10.5296/ijim.v1i1.897

\begin{abstract}
Life Insurance Corporation of India, the capital intensive business, provides the most important financial instrument to customers aimed at protection as well as long term savings. The Corporation reaches out to the people through the main traditional route of the agency model for the selling processes of the numerous complex need-based products. The agents help in marketing its policies by spreading the message of life insurance among the masses. They serve as the kingpin for insurance companies seeking to provide traditional and innovative products, and focal point for customers seeking to procure insurance coverage and long term savings. The present paper investigates the factors influencing agents' perception towards Life Insurance Corporation of India. The study is based on a sample of 225 respondents taken from three cities of Punjab. Factor Analytic Approach has been performed for data analysis. The results of the factor analysis reveal that Staff co-ordination is the most important factor to influence agents' perception followed by other six factors namely: (i) Customer target; (ii) Competitive advantage predicates; (iii) Material hallmarks; (iv) Promising products and process; (v) Service enhancement; and (vi) Exclusive attention. Moreover, analysis of one way classification has also been performed to test the significant differences among the various groups of respondents across the 23-item perception scale. The results demonstrate that no significant differences exist among various groups of respondents with respect to their perception towards Life Insurance Corporation of India.
\end{abstract}

Keywords: Life Insurance, Factors, Sales, Perception, ANOVA-one way analysis 


\section{Introduction}

Sales personnel by providing enough information to the customers, enables them in forming their assessment about the products or services, which ultimately becomes customer value. Customer satisfaction and acumen orientation significantly influence the future business opportunities and if the salespersons are able to foster their relationships with the clients, clients will be more satisfied and more willing to trust, and thus secure the long term demand for the services (Tam and Wong, 2001).

According to Crosby et al. (1990) the lack of concreteness of many services of which insurance is one, increases the value of the persons responsible for delivering them. Putting the customer first, and, exhibiting trust and integrity have been found essential in selling insurance (Slattery, 1989). In marketing life insurance, insurance agents are often considered to be marketing complex services (Nik Kamariah, 1995). Insurance sales agents fully understand the customers' needs and requirements as well as build a trusting relationship between themselves and their clients to promote long-term mutually beneficial relationship (Crosby et al., 1990). The agent has to deal with the dilemma between making sales (self interest) and providing service (customer benefit) (Oakes, 1990). Customers are, therefore, likely to place a high value on their agent's integrity and advice (Zeithaml et al., 1993). Insurance agents who sell policies are not employees of the insurance companies. Rather, they work on a commission basis and thus are motivated by the volume of sales made (Annuar, 2004). This is because; insurance agents are involved in long-term commitment and a continual stream of interaction between buyer and seller. After the sale, agents also provide follow-up service and help customers make policy changes in response to changing needs (Noor and Muhamad, 2005). The company - agent link is stronger than the agent - company link, which in turn, is stronger than the customer - company link. Customer loyalty depends on how strong the agents' link with the customer is (Balachandran, 2004). Agents are the indeed ambassadors and the backbone of the insurance industry (Malliga, 2000).

Life Insurance Corporation of India (LIC), the capital intensive business, provides the most important financial instrument to customers aimed at protection as well as long term savings. The Corporation reaches out to the people through the main traditional route of the agency model for the selling processes of the numerous complex need-based products. The gigantic superstructure that LIC has evolved into over the years is in fact built on the singular efforts of the salesperson, the primary contact point of the customers who motivates and persuades them to buy an insurance product. Such a salesperson, a sole player must display highest degree of integrity and ethics to foster a trusting relationship with his clients who would be more than satisfied and willing to be buyers. At present, LIC has around 2.70 million agents and they represent more than 60 percent of the life insurance business (www.licindia.com; Lepaud, 2008). They concentrate their efforts on seeking out new clients and maintaining

relationships with the old ones. If policy holders experience a loss, agents help them to settle their insurance claims.

Clearly, the pyramid of LIC squarely rests on the back of the agents who craft the selling processes to focus more on the needs of his clients - education, home loans, marriage 
provisions, maximization of wealth, saving for future etc. The traditional market place has given way to dynamic new age professionalism and the LIC product basket has in it a variety of products catering to the needs of the different stages of life and appropriate to the risk appetite. However, the kingpin is the primary contact person - the agent. If agents are satisfied with the services or facilities provided by LIC or even with the environment prevailing in the organization, they can be able to provide efficient services to the customers and help in Corporation success. Hence, in this paper, an attempt has been made to assess the factors influencing agents' perception towards LIC. In addition, analysis of one way classification has also been performed to test the significant differences among the various groups of respondents across the perception scale.

The paper is organized into six sections. Literature is reviewed in section 2. Section 3 deals with the selection and description of the research setting, participants, measuring instrument, and statistical tools used in the analysis of data. Data analysis and results of the study have been given in section 4. Limitations and directions for further research have been discussed in section 5. Finally, the concluding remarks emerging from the study has been given.

\section{Literature Review}

Dubinsky et al. (1988) examined that when agents' sales supervisors are high on initiating structure, agents had less role ambiguity and more job satisfaction. When sales supervisors were high on consideration, agents tend to have less role conflict and higher job satisfaction. Moreover, it was concluded that role conflict apparently raises agents' role ambiguity, reduces their job satisfaction, and augments their performance. Arora (1992) found that majority of agents are dissatisfied with the functioning of LIC. Rao and Machiraju (1988) contended that a proper understanding of the environment, characteristics, strengths \& weaknesses of the available financial instruments, and the changing scenario would be of immense advantage for the proper and successful functioning of LIC marketing force. McElory et al. (1993) investigated three forms of commitment namely, job involvement, professional commitment, community commitment and their relationship to insurance agents' perceptions, attitudes, and performance. The results revealed that professional commitment demonstrated strong and pervasive relationship with job perceptions, job attitudes, and annual earned income. Community commitment exhibited only isolated effects. In addition, Job involvement was significantly associated with some specific job perceptions and attitudes but not with performance. Chung (2000) observed that 'ideological system' of control not only encourages agents to provide life-long personalized and quality services to customers, generate strong/mutual trust among agents and managers themselves, but also made agents willing to behave altruistically, in turn sustaining a warm and supportive working environment. Tam and Wong (2001) examined that satisfaction, the salesperson's self-disclosure, and relation orientation significantly influenced future insurance business opportunities. Malliga (2000) suggested that LIC should adopt special marketing strategies and modern sales techniques for better performance of the agents. Eastman et al. (2002) found that agents appeared to be more concerned about non-Internet direct marketing. Lal and Dhanda (2003) conducted a survey of agents, development officers, and employees to know their perception towards different variables viz., life insurance products, amount of premium, working conditions, training 
programmes, computerization and efficiency level etc. The study revealed that there are no significant differences in the opinion of agents, development officers, and employees with respect to the aforesaid variables. Mathew et al. (2003) found that independent agents who have ability to effectively communicate information, provide service and effectively solve customers' problems, will no doubt, be able to sustain long-term business relationship with the customers. Noor and Muhamad (2005) suggested that organizational commitment and intrinsic motivation positively influence salespeople to perform customer-orientation behaviour in their selling activities. Rajatanavin (2005) found that whole brand image of the company depends directly on the sales force and its ability to develop strong relationship with customers. Fan and Cheng (2006) suggested that life insurance companies need to train their sales representatives to an adequate standard in competencies of problem solving, communication, information technology utilization, culture compatibility, emotional intelligence, collective competence and ethics.

It is evident from the literature that most of the studies on agents have been done in foreign countries. In India, much effort has not been devoted to record the views of agents towards LIC in respect of supervisors' behaviour, training, systematization, working condition etc. thus, the present research focuses on those issues of agents' perception which are not yet considered from an Indian perspective.

\section{Research Methodology}

\subsection{Research Setting}

The study was conducted in the LIC branches located in the major cities, namely, Amritsar, Jalandhar and Ludhiana of Punjab, a progressive state of India. For choosing the sample, non-probabilistic judgment-cum-convenience sampling technique was used.

\subsection{Participants}

A sample of 350 agents was taken who were approached personally at their work places. Out of this, 256 questionnaires were received which give an approximately 73 per cent of response rate. Of these, 225 questionnaires completed in all respects, were used for the purpose of analysis.

\subsection{Measuring Instrument}

A scale of 39 statements was developed on a seven-point Likert scale ranging from 'very strongly agree' (7) to 'very strongly disagree' (1) to tap respondent's perception towards LIC. Items were finalized after consulting relevant literature and after helpful discussion and interaction with well-known development officers, managers, training executives, and agents. The items were kept short and simple. Jargon and double-barrel statements were avoided. The 39-item scale is listed in Appendix I. About 30 percent of the statements were worded negatively to reduce the risk of the respondents replying in affirmative during data collection. These were, however, reverse coded for the purpose of data analysis and thus, interpreted accordingly. The scores of these items were reversed by subtracting each scale position from the number of scale steps plus 1 (Nunnally, 1978). 
The instrument was pre-tested on 50 agents from Amritsar city. Based on the written and verbal comments, some statements were rephrased. The revised instrument was then used for main data collection.

\subsection{Statistical Tools}

Data so collected were subjected to Descriptive Statistics, Item and Reliability Analysis, Exploratory Factor Analysis using Principal Component method with Varimax rotation, Weighted Average Scores and ANOVA-one way test. This study has used SPSS 11.5 software package to analyze the data.

\section{Data Analysis and Results}

\subsection{Sample Characteristics}

As mentioned above, the study is based on a sample of 225 agents. The demographic profile of sampled agents is shown in Table 1.

In consistence with the male-dominated industry under investigation, the majority (85.3\%) of the respondents are obviously male. As reported in Update (2003), male agents continue to dominate the profession of life insurance selling. As the profession of life insurance agents demands hectic travel schedules, it is more suited to the young. Expectedly, $76 \%$ of the agents are considered young (between the ages of 21 to 40). Most of the surveyed respondents (78.2\%) are married.

It is revealed by the Table 1 that majority (80\%) of the respondents belongs to urban areas whereas 20\% are from rural areas. Most of the respondents (40.9\%) are from Amritsar, followed by (30.7\%) Ludhiana and (28.4\%) Jalandhar. In terms of academic qualifications, the minimum education requirement to be an agent is matriculation for rural and senior secondary $\left(12^{\text {th }}\right)$ for urban people. However, the majority $(50.2 \%)$ of the agents in the industry are postgraduate followed by senior secondary (23.6\%), professional $(14.7 \%)$, matriculate (6.7\%), and graduates (4.9\%). Table 1 also illustrates that as high as $35.1 \%$ of the agents fall in the monthly income range of Rs. 10001 to 20000 and as low as $16.4 \%$ of the agents get about Rs. 5000. As regards the categories or type of agents, $84 \%$ of the responding agents classified themselves as individual agents (working under the supervision of Development Officers), and rest 16 percent of the agents are working as a career/direct agents (working under the supervision of Managers). Majority of the respondents (56.4\%) are doing their job on full-time basis as the main profession. As far as the club membership is concerned, only the highly successful agents can be club member in the life insurance industry. It is found that $37.3 \%$ of the sampled respondents are club members whereas majority (62.7\%) of the agents is non-club members.

In general, the working experience of the sampled respondents is short. Majority (69.8\%) of the respondents have an experience of up to 10 years in LIC. This is in line with the age structure where most of the respondents are young (between 21 to 40 years). Besides, majority (49.8\%) of the respondents have sold more than 50 policies, whereas $20.4 \%$ of respondents account for up to 20 policies. 


\subsection{Item and Reliability Analysis}

Before applying factor analysis, item and reliability analysis was performed to retain and delete scale items for the purpose of developing reliable scale. Corrected item-to-total correlations and Cronbach's alpha statistics were employed to conduct this type of analysis. Corrected item-to-total correlations reflect the extent to which any one item is correlated with the remaining items in a set of items under consideration. Items with low corrected item-to-total correlations are candidates for deletion (Malhotra, 2007). Kerlinger (1978) recommended corrected item-to-total correlations of 0.20 or above for inclusion of items in a scale. Cronbach's alpha coefficient varies from 0 to 1 , but satisfactory value is required to be more than 0.7 for the scale to be reliable (Hair et al., 2010).

Combining both the approaches as mentioned above, reliability of the 39-items was tested by computing Cronbach alpha scores on Performance-only measurement scale. Hence, it is observed that the application of this technique has reduced the 39-item agents' perception scale to 27 -item scale. Cronbach alpha value is estimated as 0.8273 for perception of agents indicating high level of scale reliability. Cronbach alpha of the scale was well above the cut-off value of 0.70, hence, deemed acceptable (Nunnally, 1978; Nunnally and Bernstein, 1994; Sekaran, 2005; Hair et al., 2010). The corrected item-to-total correlations of the final scale ranged from 0.2009 to 0.4748 and meet the criteria as suggested by Kerlinger (1978) for inclusion of the items in a scale. The final scale came to include twenty positive and seven negative statements.

\subsection{Factor Analytic Results}

To bring out the factors influencing the perception of agents towards Life Insurance Corporation, the final 27-item perception scale was subjected to Exploratory Factor Analysis using Principal Component method with varimax rotation. However, the adequacy or appropriateness of data for factor analysis has been examined beforehand with the help of Kaiser-Meyer-Oklin (KMO) Measure of Sampling Adequacy (MSA), and Bartlett's test of sphericity. The value of KMO for overall matrix is found to be 0.761 and Bartlett's test of sphericity was highly significant $(\mathrm{p}<0.001)$, thereby indicating that the sample taken to process the factor analysis is adequate. Besides the Bartlett's Test of Sphericity and the KMO Measure of Sampling Adequacy, Communalities for all variables were also observed. Communalities values for all variables were sufficiently above 0.50 except variable 36 which pertained to 0.411; this variable was removed from the instrument as per the recommendation of Hair et al. (2010).

Hence, all the above requirements reveal that the data set is for factor analysis. Furthermore, for defining the factors clearly, two criterions have been employed. First, it was decided to delete any variable which did not load at list $( \pm)$ 0.50. Second, it was decided that a factor must be defined by at least two variables. This criterion is consistent with the observation made by Rahtz et al. (1988). After the above preliminary steps, Factor Analysis with Principal Component Analysis as an extraction method was employed on the remaining 26-item scale. Moreover, it was observed that variable 11 and 26 were cross loaded in F1 and F8, therefore (as per the recommendation of Hair et al., 2010) these variables were too 
eliminated from the instrument. After deleting variable 11 and 26, Factor Analysis was rerun on the remaining 24-item scale. After getting the revised factor structure it was again observed that in Communality Table variable 8 was pertaining to 0.440 values which is below 0.50 , therefore in order to improve the instrument, variable 8 was also eliminated and the Factor Analysis was rerun on the remaining 23-item scale. The final factor solution, which met the above said criteria, included 23-items defined by seven factors. The final scale shown in Table 2 includes sixteen positive and seven negative statements. The value of communalities $\left(\mathrm{h}^{2}\right)$ ranged from 0.539 to 0.897 for various statements.

Table 1: Demographic Characteristics of Sampled Agents $(n=225)$

\begin{tabular}{|c|c|}
\hline Demographics & No. of Agents \\
\hline $\begin{aligned} & \text { Gender } \\
& \text { - } \text { Male } \\
& \text { - } \text { Female } \\
&\end{aligned}$ & $\begin{array}{c}192(85.3) \\
33(14.7)\end{array}$ \\
\hline $\begin{array}{cl}\text { Age (in years) } \\
\text {. } & \text { Upto } 20 \\
\text {. } & 21-40 \\
\text { - } & 41-60 \\
\text { - } & \text { Above } 60 \\
\end{array}$ & $\begin{array}{c}15(6.7) \\
171(76.0) \\
37(16.4) \\
2(0.9) \\
\end{array}$ \\
\hline $\begin{aligned} & \text { Marital status } \\
& \text { - } \text { Married } \\
& \text { - } \text { Unmarried } \\
&\end{aligned}$ & $\begin{array}{c}176(78.2) \\
49(21.8)\end{array}$ \\
\hline $\begin{array}{c}\text { Place of residence } \\
\text { - } \text { Rural } \\
\text { - } \quad \text { Urban }\end{array}$ & $\begin{array}{c}45(20.0) \\
180(80.0)\end{array}$ \\
\hline $\begin{array}{cl}\text { City } & \\
\text { - } & \text { Amritsar } \\
\text { - Jalandhar } \\
\text { - Ludhiana }\end{array}$ & $\begin{array}{l}92(40.9) \\
64(28.4) \\
69(30.7)\end{array}$ \\
\hline $\begin{array}{cl}\text { Education level } \\
\text { - } \text { Matric } \\
\text { - Senior Secondary } \\
\text { - } \text { Graduate } \\
\text { - Post Graduate } \\
\text { - } \text { Professional } \\
\end{array}$ & $\begin{array}{c}15(6.7) \\
53(23.6) \\
11(4.9) \\
113(50.2) \\
33(14.7) \\
\end{array}$ \\
\hline $\begin{array}{cc}\text { Monthly salary (in Rs.) } \\
\text { - } \quad \text { Upto } 5000 \\
\text { - } \quad 5001-10000 \\
\text { - } \quad 10001-20000 \\
\text { - } \quad \text { Above } 20000 \\
\end{array}$ & $\begin{array}{l}37(16.4) \\
47(20.9) \\
79(35.1) \\
62(27.6)\end{array}$ \\
\hline $\begin{array}{l}\text { Working as } \\
\text { - Individual Agent } \\
\text { - } \quad \text { Career/Direct agent }\end{array}$ & $\begin{array}{c}189(84.0) \\
36(16.0)\end{array}$ \\
\hline $\begin{array}{cc}\text { Nature of job } \\
\text { - } & \text { Part-time } \\
\text { - } & \text { Full-time }\end{array}$ & $\begin{array}{c}98(43.6) \\
127(56.4)\end{array}$ \\
\hline $\begin{array}{c}\text { Agents' membership } \\
\text { - } \quad \text { Club member } \\
\text { - } \quad \text { Non-club member }\end{array}$ & $\begin{array}{c}84(37.3) \\
141(62.7)\end{array}$ \\
\hline 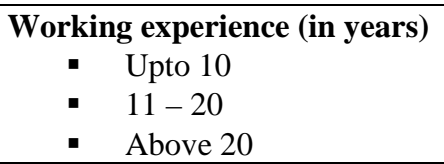 & $\begin{array}{c}157(69.8) \\
62(27.6) \\
6(2.7) \\
\end{array}$ \\
\hline
\end{tabular}


Policies Sold

- Upto 20

2011, Vol. 1, No. 1

- $21-50$

- $\quad$ Above 50

46(20.4)

$67(29.8)$

$112(49.8)$

Note: Figures in parentheses show percentages

Table 2: 23-Item (Final) Agents’ Perception Scale

\begin{tabular}{|c|c|}
\hline S. No. & Items/Statements \\
\hline S1 & $\begin{array}{l}\text { Policies/plans of LIC are superior to or more attractive than those of private insurance } \\
\text { companies }\end{array}$ \\
\hline $\mathrm{S} 2$ & Single premium policies are appropriate for avoiding lapse \\
\hline S6 & LIC provides information/details about innovations on a regular basis \\
\hline S7 & Future of LIC lies in better services and competitive products \\
\hline S10 & Performance-oriented incentives are provided \\
\hline S12 & Development officers/managers provide enough support to solve agents' problem \\
\hline *S13 & Behaviour of the supporting staff is inappropriate \\
\hline *S16 & $\begin{array}{l}\text { Agents are discouraged to put forward their points of view on organizational functioning and } \\
\text { performance }\end{array}$ \\
\hline S17 & LIC pays individual attention to the agents as much as possible \\
\hline S18 & LIC services have improved with the entry of private players in the insurance sector \\
\hline S19 & $\begin{array}{l}\text { Speedy documentation and processes at the time of issue of the policies and settlement of } \\
\text { claims }\end{array}$ \\
\hline *S20 & Medical checkup of the customers is not done properly \\
\hline S24 & Computerized information system provides best and quick services to the agents \\
\hline *S25 & Ineffective grievance redressal system for agents \\
\hline *S27 & Feedback from customers is not effectively used to improve the service standards of LIC \\
\hline S28 & LIC emphasizes quality rather than volume of sale \\
\hline S29 & $\begin{array}{l}\text { Quality plays a vital role in strengthening the LIC ability to compete in a highly competitive } \\
\text { market }\end{array}$ \\
\hline S30 & Operating hours and days of the branches are convenient \\
\hline *S32 & Location of the branch offices is inconvenient \\
\hline S34 & Drinking water and sanitary facilities are properly available \\
\hline *S35 & $\begin{array}{l}\text { Physical layout of premises and other furnishings are not comfortable for agents to interact } \\
\text { with official staff }\end{array}$ \\
\hline S37 & $\begin{array}{l}\text { LIC should impart training in special marketing strategies and modern sales techniques for the } \\
\text { better growth of agents' performance }\end{array}$ \\
\hline S38 & $\begin{array}{l}\text { LIC should arrange periodical refresher courses for agents at branch level for the effective } \\
\text { implementation of marketing strategies }\end{array}$ \\
\hline
\end{tabular}

*These items were worded negatively to reduce the tendency of the respondent replying in affirmative during data collection. They were, however, reverse coded for the purpose of data analysis and thus interpreted accordingly. 
Table 3 shows total composition of each factor that provides the information regarding items that constituted these seven factors along with their factor loadings, eigen values, Cronbach alpha values, and the variance explained by each factor. The seven factors so generated explain 70.47 percent of total variance and have eigen values between 1.093 to 4.815 . F1 explains maximum 20.93\% variance followed by F2: 14.69\%, F3: 10.25\%, F4: 7.95\%; F5: 6.34\%; F6: 5.54\%; and F7: 4.75\%.

Table 3: (Rotated) Factor Analytic Results of Agents’ Perception Scale

\begin{tabular}{|c|c|c|c|}
\hline Factors & Loading & $\begin{array}{l}\text { Eigen } \\
\text { Value }\end{array}$ & $\begin{array}{l}\text { Percent of } \\
\text { Variance }\end{array}$ \\
\hline F1 Staff Co-ordination & & 4.815 & 20.935 \\
\hline $\begin{array}{l}\text { Development officers/managers provide enough support to solve agents' } \\
\text { problem }\end{array}$ & 0.923 & & \\
\hline *Behaviour of the supporting staff is inappropriate & 0.913 & & \\
\hline *Ineffective grievance redressal system for agents & 0.898 & & \\
\hline $\begin{array}{l}\text { *Agents are discouraged to put forward their points of view on } \\
\text { organizational functioning and performance }\end{array}$ & 0.774 & & \\
\hline F2 Customer Target & & 3.380 & 14.697 \\
\hline $\begin{array}{l}\text { *Feedback from customers is not effectively used to improve the service } \\
\text { standards of LIC }\end{array}$ & 0.929 & & \\
\hline LIC emphasizes quality rather than volume of sale & 0.898 & & \\
\hline *Medical checkup of the customers is not done properly & 0.897 & & \\
\hline F3 Competitive Advantage Predicates & & 2.359 & 10.255 \\
\hline $\begin{array}{l}\text { LIC should impart training in special marketing strategies and modern } \\
\text { sales techniques for the better growth of agents' performance }\end{array}$ & 0.758 & & \\
\hline $\begin{array}{l}\text { LIC should arrange periodical refresher courses for agents at branch } \\
\text { level for the effective implementation of marketing strategies }\end{array}$ & 0.758 & & \\
\hline Future of LIC lies in better services and competitive products & 0.661 & & \\
\hline$*$ Location of the branch offices is inconvenient & 0.595 & & \\
\hline F4 Material Hallmarks & & 1.828 & 7.950 \\
\hline $\begin{array}{l}\text { *Physical layout of premises and other furnishings are not comfortable } \\
\text { for agents to interact with official staff }\end{array}$ & 0.916 & & \\
\hline Drinking water and sanitary facilities are properly available & 0.911 & & \\
\hline Operating hours and days of the branches are convenient & 0.648 & & \\
\hline F5 Promising Products and Process & & 1.457 & 6.336 \\
\hline $\begin{array}{l}\text { Speedy documentation and processes at the time of issue of the policies } \\
\text { and settlement of claims }\end{array}$ & 0.757 & & \\
\hline Single premium policies are more appropriate for avoiding lapse & 0.682 & & \\
\hline $\begin{array}{l}\text { Policies/plans of LIC are superior to or more attractive than private } \\
\text { insurance companies }\end{array}$ & 0.673 & & \\
\hline Performance-oriented incentives are provided & 0.593 & & \\
\hline F6 Service Enhancement & & 1.275 & 5.544 \\
\hline $\begin{array}{l}\text { Computerized information system provides best and quick services to the } \\
\text { agents }\end{array}$ & 0.748 & & \\
\hline $\begin{array}{l}\text { LIC services have improved with the entry of private players in the } \\
\text { insurance sector }\end{array}$ & 0.639 & & \\
\hline $\begin{array}{l}\text { Quality plays a vital role in strengthening the LIC ability to compete in a } \\
\text { highly competitive market }\end{array}$ & 0.635 & & \\
\hline F7 Exclusive Attention & & 1.093 & 4.753 \\
\hline LIC pays individual attention to the agents as much as possible & 0.794 & & \\
\hline LIC provides information/details about innovations on a regular basis & 0.759 & & \\
\hline
\end{tabular}

*These items were worded negatively to reduce the tendency of the respondent replying in affirmative during 
data collection. They were, however, reverse coded for the purpose of data analysis and thus interpreted accordingly.

Thus, the above results indicate that there are seven underlying factors which reflect the perception of agents towards LIC. Agents perceive that Staff co-ordination as the most important feature of service. Customer target is also adjudged as the second most important feature followed by Competitive advantage predicates, Material hallmarks, Promising product \& process, Service enhancement, and Exclusive attention.

Table 4: Inter-Factor Correlations, Facto-Wise Mean, Standard Deviation, and Cronbach’s Alpha of Extracted Factors (Sub Scales)

\begin{tabular}{|l|l|r|r|r|r|r|r|r|}
\hline & Factor (sub-scale) & \multicolumn{1}{|c|}{ F1 } & \multicolumn{1}{|c|}{ F2 } & \multicolumn{1}{c|}{ F3 } & \multicolumn{1}{c|}{ F4 } & \multicolumn{1}{c|}{ F5 } & \multicolumn{1}{c|}{ F6 } & \multicolumn{1}{c|}{ F7 } \\
\hline F1 & Staff Co-ordination & 1 & 0.035 & -0.108 & 0.093 & 0.029 & 0.013 & 0.170 \\
\hline & & & $(0.602)$ & $(0.107)$ & $(0.164)$ & $(0.668)$ & $(0.841)$ & $(0.011)$ \\
\hline F2 & Customer Target & & 1 & 0.249 & 0.220 & 0.279 & 0.155 & 0.083 \\
\hline & & & & $(0.000)$ & $(0.001)$ & $(0.000)$ & $(0.020)$ & $(0.217)$ \\
\hline F3 & Competitive Advantage Predicates & & & 1 & 0.151 & 0.451 & 0.440 & 0.154 \\
\hline & & & & & $(0.024)$ & $(0.000)$ & $(0.000)$ & $(0.021)$ \\
\hline F4 & Material Hallmarks & & & & & 0.170 & 0.064 & 0.059 \\
\hline & & & & & & $(0.011)$ & $(0.341)$ & $(0.379)$ \\
\hline F5 & Promising Products and Process & & & & & & 0.262 & 0.269 \\
\hline & & & & & & & $(0.000)$ & $(0.000)$ \\
\hline F6 & Service Enhancement & & & & & & & 0.120 \\
\hline & & & & & & & & $(0.073)$ \\
\hline F7 & Exclusive Attention & & & & & & & 1 \\
\hline & Number of Statements & 4 & 3 & 4 & 3 & 4 & 3 & 2 \\
\hline & Mean (Scale Value) & 4.38 & 4.77 & 6.08 & 3.94 & 5.80 & 5.97 & 4.91 \\
\hline & Standard Deviation & 1.97 & 1.72 & 1.13 & 1.96 & 1.35 & 1.15 & 1.72 \\
\hline & Alpha Value & 0.9110 & 0.9201 & 0.7012 & 0.8148 & 0.6848 & 0.5897 & 0.6435 \\
\hline
\end{tabular}

Composite Cronbach's Alpha $=0.8025$

The inter-factor correlations, factor-wise mean and standard deviation are reported in Table 4. Besides, the factor-wise alpha is also shown, which ranges from 0.5897 to 0.9201 thereby indicating high reliability of the sub-scales measuring the agents' perception. The composite alpha for the entire scale is also found to be quite high $(0.8025)$. It is thus clear from this Table that significant relationship exist between the factors, although these factors were conceptually distinct from one another as shown in the results of Principal Component Method discussed earlier.

\subsection{ANOVA-One Way Analysis}

ANOVA-one way classification was performed to test whether any significant difference existed among the various groups of respondents across 23-item perception scale. Five groups of the respondents that are considered for ANOVA-one way analysis are education level (five categories), working experience (three categories), type of agents (two categories), 
club membership (two categories) and number of policies sold (three categories). In the present study following hypothesis has been formulated and tested:

$\mathbf{H}_{\mathbf{0}}$ : There is no significant difference between the education level of the respondents and their perception.

$\mathbf{H}_{\mathbf{0 1}}$ : There is no significant difference between the working experience of the respondents and their perception.

$\mathbf{H}_{\mathbf{0 2}}$ : There is no significant difference between the type of agents of the respondents and their perception.

$\mathbf{H}_{03}$ : There is no significant difference between the club membership of the respondents and their perception.

$\mathbf{H}_{\mathbf{0 4}}$ : There is no significant difference between the number of policies sold by the respondents and their perception.

For the purpose of analysis, Weighted Average Scores (WAS) have been calculated (see Table 5). For the rejection of null hypothesis it is required that $\mathrm{p}$ value should be less than 0.05 . From the Table 6 it may observed that the probability values (p) for all the groups higher than 0.05 (level of significance), and therefore the null hypotheses (at 95 percent confidence level) may be accepted. It can be concluded that there is no significant difference among various groups of respondents with respect to their perception towards Life Insurance Corporation of India for 23-item scale.

\subsection{Implications}

The findings of the study show that the above discussed seven factors play a vital role in influencing the perception of agents toward LIC. Staff co-ordination is the key factor having impact on agents' perception. Therefore, staff should be more efficient to provide enough support in agents selling activities. In addition, other factors that agents are concerned at life insurance sector are Customer target, Competitive advantage predicates, Material hallmarks, Promising products \& process, Service enhancement, and Exclusive attention. Life Insurance Corporation of India must specify the weight of each factor having impact on agents' perception. Based on the relevance of each of these factors, life insurance industry can propose appropriate action plans to improve agents' performance as well as its profitability.

\section{Limitations and Further Research}

Firstly, this study was carried out mainly in Punjab; therefore, the results obtained may not be pertinent to the country as a whole. Of course, the study can be extended to other states of India. Secondly, the present study has been conducted by taking a sample of 337 agents of Life Insurance Corporation (a public company), ignoring the private life insurance companies. This cannot lead to the generalizability of the findings and the results may not be implied conclusively to the whole life insurance industry. Additional studies are recommended to fill this gap. Thirdly, in the current study, exploratory factor analysis using principal component method with varimax rotation has been used. Moreover, the results of this study may further 
be validated by employing confirmatory factor analysis technique. Finally, these limitations may decrease the ability of generalizing the results of this study to other life insurance companies' settings. Therefore, the conceptual and methodology limitations of this study need to be considered when designing future research.

Table 5: Agents’ Perception 23-item Scale - An Analysis of Weighted Average Scores of Demographic Groups

\begin{tabular}{|c|c|c|c|c|c|c|c|c|c|c|c|c|c|c|c|c|}
\hline $\begin{array}{c}\text { Statement } \\
/ \\
\text { Items }\end{array}$ & & & $\begin{array}{c}\text { Education } \\
\text { Level }\end{array}$ & & & & $\begin{array}{c}\text { Working } \\
\text { Experien } \\
\text { ce }\end{array}$ & & & $\begin{array}{l}\text { Type } \\
\text { of } \\
\text { Agen } \\
\text { ts }\end{array}$ & & $\begin{array}{l}\text { Club } \\
\text { Memb } \\
\text { ership }\end{array}$ & & $\begin{array}{c}\text { Numb } \\
\text { er of } \\
\text { Policie } \\
\text { s Sold }\end{array}$ & & $\begin{array}{c}\text { WA } \\
\text { S }\end{array}$ \\
\hline & EL1 & EL2 & EL3 & EL4 & EL5 & WE1 & WE2 & WE3 & TA1 & TA2 & CM1 & CM2 & PS1 & PS2 & PS3 & \\
\hline S12 & 5.27 & 4.74 & 4.82 & 5.09 & 3.82 & 4.86 & 4.63 & 5.67 & 4.75 & 5.19 & 4.65 & 4.91 & 4.87 & 5.19 & 4.57 & 4.82 \\
\hline S13 & 4.87 & 4.53 & 4.73 & 4.76 & 3.82 & 4.64 & 4.32 & 5.33 & 4.57 & 4.61 & 4.42 & 4.67 & 4.33 & 4.99 & 4.43 & 4.57 \\
\hline S25 & 4.60 & 4.04 & 4.18 & 4.37 & 3.73 & 4.09 & 4.34 & 5.83 & 4.22 & 4.11 & 4.27 & 4.16 & 3.93 & 4.28 & 4.27 & 4.20 \\
\hline S16 & 3.93 & 3.79 & 4.55 & 4.21 & 3.00 & 4.00 & 3.69 & 4.67 & 3.91 & 4.06 & 4.15 & 3.80 & 3.83 & 3.96 & 3.96 & 3.93 \\
\hline S27 & 4.67 & 4.66 & 4.91 & 4.73 & 4.33 & 4.55 & 4.94 & 4.67 & 4.72 & 4.36 & 4.71 & 4.63 & 4.20 & 4.79 & 4.78 & 4.66 \\
\hline S28 & 4.40 & 4.77 & 5.55 & 4.96 & 4.64 & 4.73 & 5.11 & 5.50 & 4.92 & 4.53 & 4.93 & 4.82 & 4.24 & 4.93 & 5.07 & 4.86 \\
\hline S20 & 4.67 & 4.64 & 5.09 & 4.84 & 4.91 & 4.66 & 5.10 & 5.67 & 4.86 & 4.53 & 4.87 & 4.77 & 4.37 & 4.78 & 5.00 & 4.80 \\
\hline S37 & 5.73 & 6.21 & 6.64 & 6.23 & 6.39 & 6.15 & 6.44 & 6.50 & 6.26 & 6.11 & 6.51 & 6.07 & 5.59 & 6.09 & 6.59 & 6.24 \\
\hline S38 & 6.13 & 6.21 & 6.36 & 6.23 & 6.33 & 6.20 & 6.32 & 6.50 & 6.27 & 6.08 & 6.49 & 6.09 & 5.63 & 6.16 & 6.54 & 6.24 \\
\hline S07 & 5.93 & 6.09 & 6.27 & 6.42 & 6.00 & 6.28 & 6.11 & 6.67 & 6.32 & 5.86 & 6.50 & 6.09 & 5.76 & 6.22 & 6.46 & 6.24 \\
\hline S32 & 5.07 & 5.83 & 5.64 & 5.52 & 5.67 & 5.52 & 5.81 & 5.17 & 5.57 & 5.69 & 5.73 & 5.51 & 4.98 & 5.67 & 5.79 & 5.59 \\
\hline S35 & 4.07 & 3.36 & 4.36 & 3.35 & 3.03 & 3.57 & 2.90 & 4.17 & 3.34 & 3.69 & 3.27 & 3.48 & 3.26 & 3.85 & 3.19 & 3.40 \\
\hline S34 & 3.80 & 3.53 & 5.00 & 3.69 & 3.21 & 3.79 & 3.24 & 4.33 & 3.63 & 3.75 & 3.68 & 3.64 & 3.22 & 4.07 & 3.58 & 3.65 \\
\hline S30 & 4.40 & 4.75 & 5.36 & 4.68 & 4.97 & 4.71 & 4.89 & 4.67 & 4.69 & 5.11 & 4.88 & 4.68 & 4.43 & 4.93 & 4.79 & 4.76 \\
\hline S19 & 5.00 & 5.40 & 5.91 & 5.28 & 5.55 & 5.17 & 5.77 & 6.00 & 5.30 & 5.69 & 5.50 & 5.28 & 4.74 & 5.18 & 5.72 & 5.36 \\
\hline S02 & 5.93 & 5.68 & 6.55 & 6.06 & 5.91 & 5.91 & 6.05 & 6.50 & 5.97 & 5.94 & 6.26 & 5.79 & 5.35 & 5.76 & 6.34 & 5.96 \\
\hline S01 & 6.33 & 6.47 & 6.73 & 6.58 & 6.36 & 6.43 & 6.66 & 7.00 & 6.49 & 6.61 & 6.64 & 6.43 & 5.85 & 6.57 & 6.75 & 6.51 \\
\hline S10 & 5.27 & 5.40 & 5.82 & 5.35 & 5.15 & 5.25 & 5.55 & 5.83 & 5.36 & 5.31 & 5.61 & 5.20 & 4.93 & 5.12 & 5.66 & 5.35 \\
\hline S24 & 5.67 & 5.70 & 6.00 & 6.04 & 5.73 & 5.92 & 5.84 & 5.50 & 6.02 & 5.19 & 6.12 & 5.75 & 5.61 & 5.87 & 6.02 & 5.89 \\
\hline S18 & 5.80 & 5.87 & 6.36 & 6.02 & 5.55 & 5.85 & 6.03 & 6.50 & 5.94 & 5.78 & 6.30 & 5.69 & 5.24 & 5.72 & 6.31 & 5.92 \\
\hline S29 & 6.13 & 6.09 & 6.27 & 6.09 & 6.09 & 6.11 & 6.03 & 6.50 & 6.23 & 5.44 & 6.15 & 6.07 & 5.87 & 5.96 & 6.29 & 6.10 \\
\hline S17 & 4.27 & 4.91 & 5.27 & 4.50 & 3.70 & 4.54 & 4.44 & 4.33 & 4.47 & 4.67 & 4.44 & 4.54 & 4.67 & 4.43 & 4.47 & 4.50 \\
\hline S06 & 4.87 & 5.70 & 5.91 & 5.45 & 4.27 & 5.39 & 5.16 & 5.00 & 5.28 & 5.53 & 5.48 & 5.23 & 5.30 & 5.31 & 5.33 & 5.32 \\
\hline
\end{tabular}


Table 6: ANOVA - one way analysis Results

\begin{tabular}{|l|l|l|l|l|l|l|}
\hline Group & $\begin{array}{l}\text { F-Value } \\
\text { (Within } \\
\text { Groups) }\end{array}$ & d.f & $\begin{array}{l}\text { Significance } \\
\text { at 5 percent } \\
\text { level }\end{array}$ & $\begin{array}{l}\text { Significant } \\
\text { /Insignificant }\end{array}$ & Hypothesis & Rejected \\
\hline Education Level & 1.874 & 4 & 0.120 & Insignificant & $\mathrm{H}_{0}$ & Accepted \\
\hline Working Experience & 1.624 & 2 & 0.205 & Insignificant & $\mathrm{H}_{01}$ & Accepted \\
\hline Type of Agents & 0.043 & 1 & 0.836 & Insignificant & $\mathrm{H}_{02}$ & Accepted \\
\hline Club Membership & 0.471 & 1 & 0.496 & Insignificant & $\mathrm{H}_{03}$ & Accepted \\
\hline $\begin{array}{l}\text { Number of Policies } \\
\text { Sold }\end{array}$ & 2.215 & 2 & 0.117 & Insignificant & $\mathrm{H}_{04}$ & Accepted \\
\hline
\end{tabular}

\section{Conclusion}

Success and overall growth potential of the insurance business depend on the efforts being made by the insurance companies in selling insurance products and services to the policyholders. Selling insurance products is a smart strategy and the real challenge is to retain and service the customer in the vibrant multiplayer competitive industry. Agents serve as the kingpin for insurance companies seeking to provide traditional and innovative products, and focal points for customers seeking to procure insurance coverage and long term saving. The factor analytic result of the present study reveals that there are seven factors influencing the perception of agents towards their organization. Agents perceive Staff co-ordination as the most important factor followed by other factors, viz., Customer target, Competitive advantage predicates, Material hallmarks, Promising products \& process, Service enhancement, and Exclusive attention. Hence, the agency system and its agents are vital factors to a company's performance and its long-term survival in the face of increased competition (Annua, 2004). Firms that want their salespeople to engage in customer oriented selling must be certain that their salespeople are committed to the organization and must be intrinsically motivated (Noor and Muhamad, 2005). If agents are satisfied with their organization in every respect (efficiency of supporting staff and their behaviour, training/refresher courses, working environment etc.) then they can provide efficient services to the policyholders and which would increase the brand image of the Corporation. So, LIC should consider its agency system as the most crucial distribution channel and should make efforts to provide them efficient facilities to improve its business performance to a great extent.

In addition, ANOVA-one way test results of five groups (education, working experience, type of agent, club membership, and number of policies sold) revealed that no significant differences has been observed between the respondents' groups and their perception across 
23-item scale.

\section{References}

Annuar, Hairul Azlan (2004), “Al-Wakalah and customers’ preferences toward it: a case study of two takaful companies in Malaysia”, also available at http//i-epistemology.net/attachments

Arora, R.S (1992), Marketing of services: a study of LIC in Jalandhar division, Ph.D Thesis, Guru Nanak Dev University, Amritsar.

Balachandran, S (2004), Customer-driven services management (2nd edition), Response Books (a division of sage publications), New Delhi.

Chung, Yan I.P (2000), Managing the service workplace: a case study of life insurance industry in Hong Kong, University of Warwick, Hong Kong.

Crosby, L.A., Evans, K.R. \& Cowles, D. (1990), "Relationship quality in services selling: an interpersonal influence perspectives”, Journal of Marketing Research, 54(3): 68-81.

Dubinsky, Alan J. \& Francis, J. Yammarino (1985), "Job-related responses of insurance agents: a multi-firm investigation”, The Journal of Risk and Insurance, 52 (3): 501-517. http://dx.doi.org/10.2307/252783

Dubinsky, Alan J., Childers, Terry L., Skinner, Steven J. \& Gencturk, Esra, (1988), “Impact of sales supervisor leadership behaviour on insurance agent attitudes and performance”, The Journal of Risk and Insurance, 55 (1): 132- 144. http://dx.doi.org/10.2307/253285

Eastman, Kevin L., Eastman, Jacqueline, K. \& Eastman, Alan D. (2002), “Issues in marketing on-line insurance products: an exploratory look at agents' use, attitudes and views of the impact of the Internet”, Risk Management and Insurance Review, 5 (2): 117-134. http://dx.doi.org/10.1111/1098-1616.00013

Fan, Chiang Ku \& Cheng, Chen-Liang (2006), “A study to identify the training needs of life insurance sales representatives in Taiwan using the Delphi approach”, International Journal $\begin{array}{lllll}\text { of Training } \quad \text { and } & \text { Development, } & \text { (3): }\end{array}$ http://dx.doi.org/10.1111/j.1468-2419.2006.00255.x

Hair, J.F., Black, W.C., Babin, B.J. \& Anderson, R.E. (2010), Multivariate data analysis, (7th edition), Prentice Hall, Upper Saddle River, New Jersey.

Kerlinger, F. N. (1978), Foundations of behavioral research, McGraw-Hill, New York.

Lepaud, Jean Pierre (2008), “Unit linked business”, IRDA Journal, 6(5): 12-14.

Lal, R. \& Dhanda, N. (2003), “Life Insurance Corporation of India devising its strategies to meet the challenges of insurance sector reforms", National seminar on emerging trends in financial services and international business, Guru Jambheshwar University, Hisar.

Malhotra, N.K. (2007), Marketing research: an applied orientation (5th edition), Pearson Education Asia, New Delhi, India. 
Malliga, R. (2000), “Marketing of LIC policies - a study on agents of Tirunelveli division”, Indian Journal of Marketing, 12 (8-10): 6-9.

Mathew, Joseph, Stone, George \& Anderson, Krista (2003), “Insurance customers' assessment of service quality: a critical evaluation”, Journal of Small Business and Enterprise Development, 10 (1): 81-92. http://dx.doi.org/10.1108/14626000310461222

McElory, James C., Morrow, Paula C., Pawer, Mark L. \& Zafar, Iqbal (1993), “Commitment and insurance agents' job perceptions, attitudes, and performance”, The Journal of Risk and Insurance, 60 (3): 363-384. http://dx.doi.org/10.2307/253034

Nik Kamariah, Nik Mat (1995), "Determinants of sales performance in insurance industry: a cross-cultural comparison between the UK and Malaysia”, Ph.D thesis, The University of Aston in Birmingham.

Noor, Nor Azila Mohd \& Muhamad, Azli (2005), "Individual factors that predict customer-orientation behaviour of Malaysian life insurance agents”, Journal Pengurusan, 24:125-149.

Nunnally, J.C. (1967), Psychometric theory, New York, Tata McGraw-Hill.

Nunnally, J. (1978), Psychometric theory (2nd edition), McGraw-Hill, New York.

Nunnally, J.C. and Bernstein, I. (1994), Psychometric theory, McGraw-Hill, New York.

Oakes, Guy (1990b), “The American life insurance salesman: a secular theodicy”, International Journal of Politics, Culture, and Society, 4: 95-112. http://dx.doi.org/10.1007/BF01384772

Rajatanavin, Ranchana (2005), “The relationship is the brand: sales reps and competitive advantage in Thai life insurance”, SERVSIG Research Conference, 2 - 4 June, Special Session: Sales and service relationships in modern asian marketing, Grand Copthorne Waterfront Hotel \& NUS Business School, National University of Singapore, Singapore.

Rao, B.S.R. \& Machiraju, A. (1988), "Life insurance and emerging trends in financial services market”, Yogaksheema, 32 (1): 25-27.

Rehtz, Don R., Sirgy, M. Joseph. \& Kosenko, Rustan (1988), "Using demographics and psychographic dimensions to discriminate between mature heavy and light television users: an exploratory analysis”, Developments in Marketing Science, Vol. 11, Edited by Kenneth Bahn, Blacksburg, VA: Academy of Marketing Science, pp 2-7.

Slattery, T. (1989), “Special report: Nichols: we've forgotten the consumer”, National Underwriter, 48 (November), 11.

Sekaran, U. (2005), Research methods for business - a skill building approach (4th edition), John Wiley \& Sons, New York.

Tam, Jackie L.M. and Wong, Y.H. (2001), "Interactive selling: a dynamic framework for services”, Journal of Services Marketing, 15 (5): 379 - 396. 
Update (2003), “Life insurance association of Malaysia”, 14(1): 14-17.

Zeithaml, V. A., Berry, L. L. \& Parsuraman, A. (1993), “The nature and determinants of customer expectations of service”, Journal of the Academy of Marketing Science, 21(1); 1-12. http://dx.doi.org/10.1177/0092070393211001

\section{Glossary}

LIC: Life Insurance Corporation

\section{Appendix 1: 39-item (Initial) Perception Scale of Life Insurance Agents}

\begin{tabular}{|c|c|}
\hline S. No. & Items/Statements \\
\hline $\mathrm{S} 1$ & Policies/plans of LIC are superior to or more attractive than those of private insurance companies \\
\hline S2 & Single premium policies are appropriate for avoiding lapse \\
\hline S3 & Customers prefer to buy new policies with excellent features and let their existing policies lapse \\
\hline S4* & Amount of premium charged in relation to the sum assured is high \\
\hline S5* & Rate of return on insurance products is lower than other saving instruments \\
\hline S6 & LIC provides information/details about innovations on a regular basis \\
\hline S7 & Future of LIC lies in better services and competitive products \\
\hline S8 & First year commission on policies is reasonable and paid on regular basis \\
\hline S9* & Renewal commission on policies is not reasonable \\
\hline S10 & Performance-oriented incentives are provided \\
\hline S11 & $\begin{array}{l}\text { Development officers/managers are well trained and have proper knowledge of policies/schemes to guide } \\
\text { the agents' selling activities properly }\end{array}$ \\
\hline $\mathrm{S} 12$ & Development officers/managers provide enough support to solve agents’ problem \\
\hline S13* & Behaviour of the supporting staff is inappropriate \\
\hline S14 & $\begin{array}{l}\text { Agents mostly sell and promote those policies/schemes that are beneficial to them in terms of higher } \\
\text { commission }\end{array}$ \\
\hline S15 & Sometimes agents face rivalry from other agents in carrying on their business \\
\hline S16* & Agents are discouraged to put forward their points of view on organizational functioning and performance \\
\hline S17 & LIC pays individual attention to the agents as much as possible \\
\hline S18 & LIC services have improved with the entry of private players in the insurance sector \\
\hline S19 & Speedy documentation and processes at the time of issue of the policies and settlement of claims \\
\hline $\mathrm{S} 20 *$ & Medical checkup of the customers is not done properly \\
\hline S21 & Advertisement support agents' selling activities to a large extent \\
\hline S22* & $\begin{array}{l}\text { Media, theme layout and language are not used properly in advertisement for attracting the attention of } \\
\text { customers }\end{array}$ \\
\hline $\mathrm{S} 23$ & $\begin{array}{l}\text { Customer service through Internet certainly affects the efficiency level to a large extent besides improving } \\
\text { the service quality }\end{array}$ \\
\hline S24 & Computerized information system provides best and quick services to the agents \\
\hline S25* & Ineffective grievance redressal system for agents \\
\hline S26 & Training programmes, refresher courses and regular meetings with development officers/managers update \\
\hline
\end{tabular}




\begin{tabular}{|c|l|}
\hline & agents about products and services \\
\hline S27* & Feedback from customers is not effectively used to improve the service standards of LIC \\
\hline S28 & LIC emphasizes quality rather than volume of sale \\
\hline S29 & Quality plays a vital role in strengthening the LIC ability to compete in a highly competitive market \\
\hline S30 & Operating hours and days of the branches are convenient \\
\hline S31 & $\begin{array}{l}\text { Bancassurance can be the cost effective channel in providing better services along with the increment in } \\
\text { average premium income of LIC }\end{array}$ \\
\hline S32* & Location of the branch offices is inconvenient \\
\hline S33* & Parking facility at branch offices is not convenient \\
\hline S34 & Drinking water and sanitary facilities are properly available \\
\hline S35* & $\begin{array}{l}\text { Physical layout of premises and other furnishings are not comfortable for agents to interact with official } \\
\text { staff }\end{array}$ \\
\hline S36 & LIC promotes ethical conduct in everything it does \\
\hline S37 & $\begin{array}{l}\text { LIC should impart training in special marketing strategies and modern sales techniques for the better } \\
\text { growth of agents' performance }\end{array}$ \\
\hline S38 & $\begin{array}{l}\text { LIC should arrange periodical refresher courses for agents at branch level for the effective implementation } \\
\text { of marketing strategies }\end{array}$ \\
\hline S39 & $\begin{array}{l}\text { LIC should expand the modern and alternate mode of premium payment, such as electronic clearing system, } \\
\text { direct debit from customers' bank account, payment through Internet etc. }\end{array}$ \\
\hline
\end{tabular}

*These items were worded negatively to reduce the tendency of the respondents replying in affirmative during data collection. They were, however, reverse coded for the purpose of data analysis and thus interpreted

Appendix 2: KMO and Bartlett's Test

\begin{tabular}{|l|l|r|}
\hline Kaiser-Meyer-Olkin Measure of Sampling Adequacy. & & 0.761 \\
\hline Bartlett's Test of Sphericity & Approx. Chi-Square & 3059.393 \\
\hline & df & 351 \\
\hline & Sig. & .000 \\
\hline
\end{tabular}

Appendix 3: Communalities

\begin{tabular}{|l|c|c|}
\hline & Initial & Extraction \\
\hline VAR00001 & 1 & 0.562 \\
\hline VAR00002 & 1 & 0.585 \\
\hline VAR00006 & 1 & 0.708 \\
\hline VAR00007 & 1 & 0.518 \\
\hline VAR00008 & 1 & 0.642 \\
\hline VAR00010 & 1 & 0.564 \\
\hline VAR00011 & 1 & 0.758 \\
\hline VAR00012 & 1 & 0.855 \\
\hline VAR00013 & 1 & 0.835 \\
\hline VAR00016 & 1 & 0.703 \\
\hline VAR00017 & 1 & 0.687 \\
\hline
\end{tabular}




\begin{tabular}{|l|l|l|}
\hline VAR00018 & 1 & 0.610 \\
\hline VAR00019 & 1 & 0.674 \\
\hline VAR00020 & 1 & 0.828 \\
\hline VAR00024 & 1 & 0.636 \\
\hline VAR00025 & 1 & 0.755 \\
\hline VAR00026 & 1 & 0.722 \\
\hline VAR00027 & 1 & 0.898 \\
\hline VAR00028 & 1 & 0.876 \\
\hline VAR00029 & 1 & 0.549 \\
\hline VAR00030 & 1 & 0.649 \\
\hline VAR00032 & 1 & 0.644 \\
\hline VAR00034 & 1 & 0.853 \\
\hline VAR00035 & 1 & 0.842 \\
\hline VAR00036 & $\mathbf{1}$ & $\mathbf{0 . 4 1 1}$ \\
\hline VAR00037 & 1 & 0.712 \\
\hline VAR00038 & 1 & 0.707 \\
\hline
\end{tabular}

Appendix 4: Rotated Component Matrix

\begin{tabular}{|c|c|c|c|c|c|c|c|c|}
\hline & 1 & 2 & 3 & 4 & 5 & 6 & 7 & 8 \\
\hline VAR00012 & 0.917 & & & & & & & \\
\hline VAR00013 & 0.91 & & & & & & & \\
\hline VAR00025 & 0.862 & & & & & & & \\
\hline VAR00016 & 0.755 & & & & & & & \\
\hline VAR00011 & 0.684 & & & & & & & 0.514 \\
\hline VAR00026 & 0.648 & & & & & & & 0.514 \\
\hline VAR00027 & & 0.932 & & & & & & \\
\hline VAR00028 & & 0.903 & & & & & & \\
\hline VAR00020 & & 0.891 & & & & & & \\
\hline VAR00038 & & & 0.771 & & & & & \\
\hline VAR00037 & & & 0.769 & & & & & \\
\hline VAR00007 & & & 0.628 & & & & & \\
\hline VAR00032 & & & 0.543 & & & & & \\
\hline VAR00035 & & & & 0.899 & & & & \\
\hline VAR00034 & & & & 0.896 & & & & \\
\hline VAR00030 & & & & 0.679 & & & & \\
\hline VAR00019 & & & & & 0.754 & & & \\
\hline VAR00002 & & & & & 0.692 & & & \\
\hline VAR00001 & & & & & 0.678 & & & \\
\hline VAR00010 & & & & & 0.595 & & & \\
\hline VAR00024 & & & & & & 0.755 & & \\
\hline VAR00029 & & & & & & 0.627 & & \\
\hline VAR00018 & & & & & & 0.611 & & \\
\hline
\end{tabular}




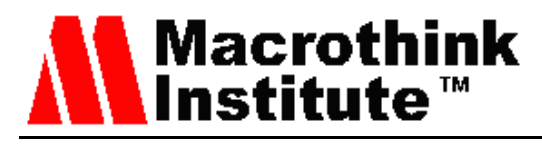

International Journal of Industrial Marketing

ISSN 2162-3066

2011, Vol. 1, No. 1

\begin{tabular}{|l|l|l|l|l|l|l|l|l|} 
VAR00017 & & & & & & 0.824 & \\
\hline VAR00006 & & & & & & & 0.785 & \\
\hline VAR00008 & & & & & & & -0.597 \\
\hline
\end{tabular}

Extraction Method: Principal Component Analysis.

Rotation Method: Varimax with Kaiser Normalization.

A Rotation converged in 7 iterations. 
Appendix 5: Communalities

\begin{tabular}{|l|c|c|}
\hline & Initial & Extraction \\
\hline VAR00001 & 1 & 0.556 \\
\hline VAR00002 & 1 & 0.576 \\
\hline VAR00006 & 1 & 0.617 \\
\hline VAR00007 & 1 & 0.529 \\
\hline VAR00008 & $\mathbf{1}$ & $\mathbf{0 . 4 4 0}$ \\
\hline VAR00010 & 1 & 0.533 \\
\hline VAR00012 & 1 & 0.866 \\
\hline VAR00013 & 1 & 0.847 \\
\hline VAR00016 & 1 & 0.727 \\
\hline VAR00017 & 1 & 0.662 \\
\hline VAR00018 & 1 & 0.593 \\
\hline VAR00019 & 1 & 0.664 \\
\hline VAR00020 & 1 & 0.826 \\
\hline VAR00024 & 1 & 0.652 \\
\hline VAR00025 & 1 & 0.819 \\
\hline VAR00027 & 1 & 0.892 \\
\hline VAR00028 & 1 & 0.861 \\
\hline VAR00029 & 1 & 0.545 \\
\hline VAR00030 & 1 & 0.583 \\
\hline VAR00032 & 1 & 0.530 \\
\hline VAR00034 & 1 & 0.861 \\
\hline VAR00035 & 1 & 0.867 \\
\hline VAR00037 & 1 & 0.708 \\
\hline VAR00038 & 1 & 0.707 \\
\hline
\end{tabular}


Appendix 6: Communalities

\begin{tabular}{|l|c|c|} 
& Initial & Extraction \\
\hline VAR00001 & 1 & 0.558 \\
\hline VAR00002 & 1 & 0.575 \\
\hline VAR00006 & 1 & 0.679 \\
\hline VAR00007 & 1 & 0.585 \\
\hline VAR00010 & 1 & 0.545 \\
\hline VAR00012 & 1 & 0.866 \\
\hline VAR00013 & 1 & 0.847 \\
\hline VAR00016 & 1 & 0.729 \\
\hline VAR00017 & 1 & 0.676 \\
\hline VAR00018 & 1 & 0.607 \\
\hline VAR00019 & 1 & 0.666 \\
\hline VAR00020 & 1 & 0.833 \\
\hline VAR00024 & 1 & 0.648 \\
\hline VAR00025 & 1 & 0.819 \\
\hline VAR00027 & 1 & 0.897 \\
\hline VAR00028 & 1 & 0.869 \\
\hline VAR00029 & 1 & 0.539 \\
\hline VAR00030 & 1 & 0.587 \\
\hline VAR00032 & 1 & 0.572 \\
\hline VAR00034 & 1 & 0.860 \\
\hline VAR00035 & 1 & 0.864 \\
\hline VAR00037 & & 0.699 \\
\hline VAR00038 & 1 & 0.692 \\
\hline & 1 & \\
\hline
\end{tabular}




\begin{tabular}{|c|c|c|c|c|c|c|c|c|c|}
\hline Component & $\begin{array}{c}\text { Initial } \\
\text { Eigen values }\end{array}$ & & & $\begin{array}{c}\text { Extraction Sums } \\
\text { of Squared Loadings }\end{array}$ & & & $\begin{array}{l}\text { Rotation Sums of } \\
\text { Squared Loadings }\end{array}$ & & \\
\hline & Total & $\begin{array}{c}\% \text { of } \\
\text { Variance }\end{array}$ & Cumulative \% & Total & $\begin{array}{c}\% \text { of } \\
\text { Variance }\end{array}$ & $\begin{array}{c}\text { Cumulative } \\
\%\end{array}$ & Total & $\%$ of Variance & Cumulative \% \\
\hline 1 & 4.815 & 20.935 & 20.935 & 4.815 & 20.935 & 20.935 & 3.225 & 14.021 & 14.021 \\
\hline 2 & 3.38 & 14.697 & 35.633 & 3.38 & 14.697 & 35.633 & 2.682 & 11.662 & 25.683 \\
\hline 3 & 2.359 & 10.255 & 45.888 & 2.359 & 10.255 & 45.888 & 2.394 & 10.409 & 36.093 \\
\hline 4 & 1.828 & 7.95 & 53.837 & 1.828 & 7.95 & 53.837 & 2.313 & 10.057 & 46.15 \\
\hline 5 & 1.457 & 6.336 & 60.173 & 1.457 & 6.336 & 60.173 & 2.2 & 9.564 & 55.714 \\
\hline 6 & 1.275 & 5.544 & 65.717 & 1.275 & 5.544 & 65.717 & 1.725 & 7.5 & 63.214 \\
\hline 7 & 1.093 & 4.753 & 70.47 & 1.093 & 4.753 & 70.47 & 1.669 & 7.257 & 70.47 \\
\hline 8 & 0.914 & 3.974 & 74.444 & & & & & & \\
\hline 9 & 0.769 & 3.344 & 77.788 & & & & & & \\
\hline 10 & 0.739 & 3.215 & 81.004 & & & & & & \\
\hline 11 & 0.644 & 2.8 & 83.803 & & & & & & \\
\hline 12 & 0.581 & 2.526 & 86.329 & & & & & & \\
\hline 13 & 0.485 & 2.11 & 88.439 & & & & & & \\
\hline 14 & 0.462 & 2.01 & 90.449 & & & & & & \\
\hline 15 & 0.417 & 1.814 & 92.263 & & & & & & \\
\hline 16 & 0.362 & 1.573 & 93.836 & & & & & & \\
\hline 17 & 0.329 & 1.43 & 95.266 & & & & & & \\
\hline 18 & 0.29 & 1.26 & 96.527 & & & & & & \\
\hline 19 & 0.231 & 1.006 & 97.532 & & & & & & \\
\hline 20 & 0.196 & 0.853 & 98.385 & & & & & & \\
\hline 21 & 0.147 & 0.639 & 99.023 & & & & & & \\
\hline 22 & 0.125 & 0.545 & 99.568 & & & & & & \\
\hline 23 & 0.099 & 0.432 & 100 & & & & & & \\
\hline
\end{tabular}

Extraction Method: Principal Component Analysis. 
Appendix 8: Rotated Component Matrix

\begin{tabular}{|c|c|c|c|c|c|c|c|}
\hline & 1 & 2 & 3 & 4 & 5 & 6 & 7 \\
\hline VAR00012 & 0.923 & & & & & & \\
\hline VAR00013 & 0.913 & & & & & & \\
\hline VAR00025 & 0.898 & & & & & & \\
\hline VAR00016 & 0.774 & & & & & & \\
\hline VAR00027 & & 0.929 & & & & & \\
\hline VAR00028 & & 0.898 & & & & & \\
\hline VAR00020 & & 0.897 & & & & & \\
\hline VAR00037 & & & 0.758 & & & & \\
\hline VAR00038 & & & 0.758 & & & & \\
\hline VAR00007 & & & 0.661 & & & & \\
\hline VAR00032 & & & 0.595 & & & & \\
\hline VAR00035 & & & & 0.916 & & & \\
\hline VAR00034 & & & & 0.911 & & & \\
\hline VAR00030 & & & & 0.648 & & & \\
\hline VAR00019 & & & & & 0.757 & & \\
\hline VAR00002 & & & & & 0.682 & & \\
\hline VAR00001 & & & & & 0.673 & & \\
\hline VAR00010 & & & & & 0.593 & & \\
\hline VAR00024 & & & & & & 0.748 & \\
\hline VAR00018 & & & & & & 0.639 & \\
\hline VAR00029 & & & & & & 0.635 & \\
\hline VAR00017 & & & & & & & 0.794 \\
\hline VAR00006 & & & & & & & 0.759 \\
\hline
\end{tabular}

Extraction Method: Principal Component Analysis.

Rotation Method: Varimax with Kaiser Normalization.

A Rotation converged in 6 iterations. 